\title{
"Letting the leaders pass": barriers to using traditional ecological knowledge in comanagement as the basis of formal hunting regulations
}

\author{
Elisabeth Padilla $^{1}$ and Gary P. Kofinas ${ }^{2}$
}

\begin{abstract}
We studied a case of failure in applying traditional ecological knowledge (TEK) in comanagement as the basis for formal hunting regulations. We based the study on the Porcupine Caribou (Rangifer tarandus) Herd "let the leaders pass" policy, established for the Dempster Highway of the Western Canadian Arctic, and identified conditions creating barriers in the successful application of TEK through comanagement. Stated as propositions, identified barriers include: (1) the context-specific nature of TEK limits its application in resource management regulations; (2) changes in traditional authority systems, hunting technology, and the social organization of harvesting caribou affect the effectiveness of TEK approaches in a contemporary social setting; (3) indigenous efforts toward self-government and political autonomy limit regional comanagement consensus in a heterogeneous cultural landscape; (4) the mismatch of agency enforcement of hunting regulations and TEK-based education is problematic. We analyzed the case through four historical phases of caribou management, complementing the study with a literature review of TEK and wildlife comanagement to explain why TEK integration of caribou leaders in regulatory resource management fell short of success. Identifying and understanding the social dynamics related to these barriers make apparent solutions for transforming the comanagement process.
\end{abstract}

Key Words: caribou; comanagement; traditional ecological knowledge; wildlife management

\section{INTRODUCTION}

We identified conditions that create barriers to successful application of traditional ecological knowledge (TEK) in wildlife regulations through comanagement. Our analysis is based on a case study of regulating hunting to "let the caribou leaders pass" for the Porcupine Caribou Herd ( $\mathrm{PCH})$ along the Dempster Highway of northwestern Canada.

We use the term traditional ecological knowledge (TEK) instead of indigenous knowledge or local knowledge, despite ambiguous definitional issues, because it is more specific to indigenous people's knowledge of the land (Berkes 1993, 2012). We define TEK as "a cumulative body of knowledge, practice, and belief, evolving by adaptive processes and handed down through generations by cultural transmission, about the relationship of living beings (including humans) with one another and with their environment" (Berkes 2008:7). The term comanagement is defined in multiple ways, as reviewed by Carlsson and Berkes (2005). Their review emphasized that comanagement has complexities, variations, and a dynamic nature that are not captured by most definitions. We chose to use Singleton's (1998) definition because it best reflects the ideals of comanagement in this case study: "governance systems that combine State control with local, decentralized decision making and accountability and which, ideally, combine the strengths and mitigate the weaknesses of each"(Singleton 1998:7).

\section{Caribou leaders and "letting the leaders pass" My mama always tell us don't bother 'em. Let them go through first, there be more caribou coming. And if they have a trail, caribou follow. She said don't bother 'em. So we always respected, we never bother the front caribou. (Old Crow hunter)}

The notion of letting the caribou leaders pass originates in indigenous hunting tradition. Literature on TEK describing caribou (Rangifer tarandus) leaders, i.e., caribou that lead a group or herd of caribou, is sparsely documented for indigenous caribou hunting groups. Gubser (1961) describes caribou leaders in his early ethnography of Nunamiut Eskimo at Anaktuvuk Pass, Alaska. Porcupine Caribou hunters traditionally avoided shooting caribou leaders to ensure continued migration of caribou and caribou harvest throughout the fall hunting season (Sherry and Vuntut Gwitchin First Nation 1999, Smith and Cooley 2003). Traditional hunting strategies of Inuit in the Northwest Territories show concern for deviating caribou movement from common migration routes. For example, Gunn et al. (1988) described that hunters were inconspicuous at water crossings until lead caribou crossed, so that following caribou would continue to swim across when hunters began to shoot. Similarly, Stewart et al. (2004) reported that hunters avoided butchering animals or disposing of bones near migration routes to avoid diverting caribou movement.

The tendency of a group to follow the first "leader" animal that leaves the herd is well documented for reindeer (Paine 1988, Baskin 1989). Ethnographic accounts of reindeer herding, such as those of the Saami of Fennoscandia, highlight herders' knowledge of herd leaders and their importance in directing the movements of groups of Rangifer (e.g., Paine 1994). The identification and use of leader animals to facilitate herd management is central to the practice of reindeer herding (Baskin 1989). Baskin and Hjalten (2001) described the tendency of a group of reindeer to run away following a leader, and herders consequently eliminating the most nervous animals to ease herd management. Additionally, herders used docile animals as decoys to lead a group of domestic reindeer to a new pasture, or a group of wild reindeer into ambush (Ingold 1986).

Few scientific studies have measured or systematically observed caribou leadership behavior (Miller et al. 1971, Paine 1988, Benn 2001). There is, however, a growing body of literature on leadership behavior in various species, with potential applications to population management (Bailey et al. 1998, McComb et al. 2001, Rands et al. 2003, Conradt and Roper 2005, Couzin et al.

${ }^{1}$ Resilience and Adaptation Program, University of Alaska Fairbanks, ${ }^{2}$ Department of Humans and Environment and Institute of Arctic Biology, University of Alaska Fairbanks 
2005, Dumont et al. 2005). Some have argued that the expanding human infrastructure has and/or will potentially have a negative effect on caribou (Nelleman et al. 2001). Although scientific investigation of caribou leadership is important to understanding the impact of human infrastructure and related activities on caribou movement (Benn 2001, Smith and Cooley 2003), leadership in caribou has not been measured with the scientific method. Authors have, however, described these gregarious animals as having wellestablished, learned migratory behavior with fidelity to calving grounds or crossing points (Dahle et al. 2008, Kelsall 1968). Caribou leaders could thus exist for migration purposes, and/or within temporary groups. When the Porcupine Caribou Management Board deliberated on how to address concerns about the effects of highway and harvesting caribou leaders, the body of scientific knowledge was limited.

Indigenous residents of Yukon and Northwest Territories rural communities have expressed concern that disturbing or shooting caribou leaders can cause caribou to redirect seasonal movements and abandon wintering areas in close proximity to communities (Benn 2001). Similarly Smith and Cooley (2003) reported hunters' predictions of caribou reactions to roadside disturbances. Hunters in their study based their answers on their own interactions with caribou. They found that "taking the leaders" was a predictor of how caribou react to human disruption. Participants in the study mentioned caribou leaders when talking about the location of caribou killed in a group. Respondents in that study described types of caribou leaders, including individuals or groups of animals with different behavioral roles in the herd, e.g., steering migrating groups or detecting danger.

The practice of letting the leaders pass is still supported by many northern caribou subsistence communities and some indigenous hunters, and elders have brought the concept of caribou leaders to the forefront of management discussions (e.g., PCMB 1995, Alaska Department of Fish and Game 2005). "Caribou leaders," however, are not easily defined as one particular sex or age class. Instead, "leaders" is a flexible term used in ways directly applicable to hunting traditions, and is therefore highly dependent on socialecological context (Padilla 2010). As discovered in this study, creating a formal hunting regulation based on this traditional practice is a challenge.

\section{Managing resources with TEK}

Many authors have argued that incorporating TEK into resource managers' decision making can increase resource management effectiveness (e.g., Stevenson 1996, Houck 2003, Folke 2004, Berkes and Turner 2006, Chapin et al. 2009). Early frames of "systems of knowledge" were typically dichotomized, i.e., western vs. traditional knowledge, with the opportunities for integration simplistically described. In application, several comanagement bodies of Canada were established in the late 1970s and onward to involve indigenous resource users in the wildlife management process, with some arrangements explicitly recognizing the legitimacy of local and traditional knowledge (Houde 2007). Subsequent analyses have offered more nuanced descriptions of the complexities of the process and its political underpinnings (e.g., Morrow and Hensel 1992, Huntington 2005, Kofinas 2005, Parlee et al. 2005, Berkes 2012). Reframing the discussion on TEK to social learning, Berkes (2008) described traditional knowledge and resource management as processes of "trial and error" and "learning by doing," while managing for the unknown. The recognition of multiple sources of knowledge in management indicates the potential for resource users, managers, and scientists to work together in an adaptive comanagement system for more holistic understanding and robust policies (Kendrick 2003, Armitage et al. 2007). Moving from theoretical speculation to application raises the question of if, when, and how traditional knowledge can contribute to wildlife management. This paper helps to address that question through a study of the use of TEK in formal wildlife regulations and its implementation through a comanagement process.

In 1986, the Canadian Federal Government established the Porcupine Caribou Management Board (PCMB), through the Porcupine Caribou Management Agreement (PCMA; Government of Canada et al. 1985) signed by the Yukon Territorial Government, the Government of Northwest Territories (NWT), and First Nations of the region (Peter and Urquhart 1991, Kofinas 1998). The terms of the agreement state that the board is advisory through recommendations to government ministers. Although the authority of the board is therefore limited, elected officials and agencies have deferred to the board's recommendation because of its broad representation and role as a communication and coordination body (Kofinas 1998). The creation of the agreement and its board were an effort to link local-level authority systems with higher level processes of decision making and more effectively achieve regional consensus on caribou management decisions (Kofinas 2005).

One key motivation in establishing the Canadian $\mathrm{PCH}$ comanagement arrangement was to address long-standing issues related to hunting Porcupine Caribou along the Dempster Highway, a $736 \mathrm{~km}$ gravel, two-lane road running from central Yukon Territory to Inuvik, Northwest Territories. Upon opening the Dempster Highway in 1979 (Page 1986), a range of wildlife management issues was of concern to both government officials and hunters, including safety over hunting from the Dempster Highway because of easy access, the potential abandonment of traditional hunting practices through highway hunting with trucks, and disturbance to the herd. Among the concerns was the worry that highway hunting was causing a deflection of the caribou herd migration from wintering grounds east of the highway, thus making caribou unavailable to local hunters of Northwest Territories and Yukon. Based on a recommendation from the local Tetlit Gwich'in Renewable Resource Council of Fort McPherson, NWT to the PCMB in 1994, TEK was later used by Yukon and Northwest Territorial Governments as the basis of hunting closures along the highway to let the leaders of the caribou herd pass (PCMB 2000). The absence of science-based recommendations on caribou leaders and the complete reliance on TEK as the basis for the hunting regulation set this hunting closure apart from the other hunting regulations.

\section{Exploring comanagement dynamics of "letting the caribou leaders pass"}

Achieving effective comanagement is a collective-action problem among stakeholders, including government agencies. Understanding the dynamics of the comanagement process for the let the leaders pass regulation suggests the need to consider the costs and benefits of various actors at various scales, from the individual hunter to communities, to First Nations, and territorial and federal governments, as well as the historical context from which the regulation emerged. As noted by several previous studies, comanagement is typically no panacea (Caulfield 1997, Kofinas 
1998, 2005, Nadasdy 2003a, Caulfield et al. 2004, Natcher et al. 2005). Despite early theoretical hopes of a northern wildlife comanagement leading to more effective resource management (e.g., Osherenko 1988, Usher 1986), the political conflicts of comanagement have in some cases led to significant problems (e.g., Nadasdy 2003a). Suggested in all these case studies is that the actions and reactions of governments, scientists, local community leaders, and hunters at different scales are a key consideration in the analysis of emergent comanagement challenges.

The let the leaders pass policy implementation differed in Yukon Territory from Northwest Territories, where it was not formally enforced. Our focus in this paper is on the Yukon Territory's implementation of the hunting regulation established in 2000, and its eventual rejection by the Department of Justice Canada after it was challenged by a Dawson City First Nation hunter in 2007. Table 1 shows how since its first meeting in 1986, the PCMB engaged in an ongoing process of board-level discussions, community consultations, media coverage, and workshops to address and reassess problems associated with Dempster Highway hunting, and ultimately proposed let the leaders pass hunting regulations.

We explored the case through a historical analysis of Dempster Highway hunting issues, dividing the events into four time periods or phases. These include:

- Phase One: traditional hunting (precontact-1950s),

- Phase Two: precomanagement: Dempster Highway construction to completion and signing of the Canadian PCMA (1960s-1985),

- Phase Three: caribou comanagement through the PCMB (1985-1995),

- Phase Four: comanaging caribou hunting with traditional knowledge in a new political context (1995-2009)

We describe the social-political context of indigenous caribou hunting management from the early traditional authority system to the recent PCMB comanagement arrangement, and identified barriers that prevented successful application of TEK into regulatory wildlife management. Stated as middle-range propositions, these barriers include: (1) the context-specific nature of TEK limits its application in resource management regulations; (2) changes in traditional authority systems, hunting technology, and the social organization of harvesting caribou affect the effectiveness of TEK approaches in a contemporary social setting; (3) indigenous efforts toward self-government and political autonomy limit regional comanagement consensus in a heterogeneous cultural landscape; (4) the mismatch of agency enforcement of hunting regulations and TEK-based education is problematic. Our analysis is complemented with a literature review of TEK and wildlife comanagement to explain why TEK integration of caribou leaders in regulatory resource management fell short of success.

\section{METHODS}

\section{Case study research}

We used a single case study approach to analyze the let the leaders pass policy. As defined by Yin (2009:18), a case study is "an empirical inquiry that investigates a contemporary phenomenon in depth and within its real-life context, especially when the boundaries between phenomenon and context are not clearly evident," and can provide insight into specific complex phenomena where experiential research and controlled variables are not possible. Several researchers in the past have used single case studies to assess the effectiveness of integrating TEK in government-led resource management (e.g., Richard and Pike 1993, Taiepa et al. 1997, Kendrick 2003, Nadasdy 2003a, Berkes 2008). Pinkerton (1989) elucidated the conditions for successful comanagement in her seminal analysis and other studies (Pinkerton 1994, 2009). She argued that identifying the nature of barriers and ways to overcome them in smaller scale case studies of comanagement implementation is a valuable method of analysis that can contribute to broader understanding of comanagement systems (Pinkerton 1999). Similar to Light et al. 's (1995) historical account of the Everglades, we use a "thick description" (Geertz 1973) to present data or key events relevant to the case study. We follow Pinkerton's grounded-theory approach to studying comanagement (Glaser and Strauss 1967, Strauss 1987) to identify barriers to implementing TEK-based hunting regulations through comanagement. Because of the use of the single case study approach, we note from the outset that there are inherent limitations in drawing broader generalizations about the phenomena. This suggests a need to test our four propositions in other wildlife comanagement contexts.

\section{Sources of evidence and historical account}

We studied the case of indigenous caribou hunting from the Dempster Highway using multiple sources of evidence and where possible, sought to triangulate evidence to confirm factual information (see Table 2). Research for the case study was conducted through two projects, with findings from both integrated in this analysis. The first was a Man and the Biosphere Reserve/National Science Foundation funded project (Kofinas 1998), which examined the cost of power sharing in comanagement. The second was the Master's thesis research of Padilla (2010), which focused on local hunters' definitions of caribou leaders and their perspectives on Dempster Highway hunting regulations. The former offered a foundational understanding of $\mathrm{PCH}$ comanagement and insight into historical events surrounding the let the leaders pass policy. The Kofinas study involved extensive archival research, three years of participant observation in caribou user communities, and participant observation at ten PCMB board meetings from 1992 to 1997 , including one in 1995 when let the leaders pass idea was first presented to the PCMB as a proposal by an indigenous leader. This project included unstructured interviews with key respondents, including all PCMB members and many community leaders, and over 220 structured interviews with $\mathrm{PCH}$ users from communities, as well as focus group research with Fort McPherson hunters about the Dempster highway hunting. In addition, Kofinas attended several PCMB organized workshops focused on the Dempster highway hunting problem. 
Table 1. Phases of caribou management with respect to the Dempster Highway and changes in social organization, role of traditional ecological knowledge (TEK), and wildlife management relations.

\begin{tabular}{|c|c|c|c|}
\hline Phase & $\begin{array}{l}\text { Social organization of caribou } \\
\text { harvesting by Fort McPherson residents }\end{array}$ & $\begin{array}{l}\text { Role of TEK in wildlife } \\
\text { management }\end{array}$ & Wildlife Management \\
\hline $\begin{array}{l}\text { Traditional Management } \\
\text { (precontact-1950s) }\end{array}$ & $\begin{array}{l}\text { Community hunts commons; chief or } \\
\text { hunting leader direct actions of hunters. } \\
\text { Kinship groups and individuals also } \\
\text { harvesting opportunistically. Use of } \\
\text { foot and snowshoes for mobility. }\end{array}$ & $\begin{array}{l}\text { Cultivated and highly applied by } \\
\text { indigenous hunters. Some limited } \\
\text { interest by naturalists and } \\
\text { anthropologists. }\end{array}$ & $\begin{array}{l}\text { Traditional system of caribou } \\
\text { management; state-community } \\
\text { interactions in caribou management } \\
\text { limited. }\end{array}$ \\
\hline $\begin{array}{l}\text { Pre Porcupine Caribou } \\
\text { Herd (PCH) } \\
\text { comanagement } \\
(1960 \text { s-1985) }\end{array}$ & $\begin{array}{l}\text { Dog sleds replaced with snowmobiles } \\
\text { by } 1960 \mathrm{~s} \text {; hunters use of trucks for } \\
\text { access hunting areas around the } \\
\text { Dempster. Greater individualism in } \\
\text { harvesting. }\end{array}$ & $\begin{array}{l}\text { TEK evolves at local level; state } \\
\text { management mostly dismisses } \\
\text { value of TEK and seeks scientific } \\
\text { insights for caribou management. }\end{array}$ & $\begin{array}{l}\text { Increased presence of state-dominated } \\
\text { caribou management. State agencies } \\
\text { "consult" with communities. Little to no } \\
\text { power sharing in decision making. }\end{array}$ \\
\hline $\begin{array}{l}\text { Early PCH } \\
\text { comanagement through } \\
\text { the Porcupine Caribou } \\
\text { Management Agreement } \\
\text { (PCMA; 1985-1995) }\end{array}$ & $\begin{array}{l}\text { Dempster corridor becomes most } \\
\text { common access point for caribou } \\
\text { hunting. Greater schism between youth } \\
\text { and elder perspectives on ethical } \\
\text { hunting. }\end{array}$ & $\begin{array}{l}\text { TEK gains legitimacy as } \\
\text { comanagement develops. First } \\
\text { TEK studies during this time. }\end{array}$ & $\begin{array}{l}\text { PCH comanagement system established. } \\
\text { State agencies increasingly look to } \\
\text { comanagement board for solutions to } \\
\text { issues and is responsive to board } \\
\text { recommendations. }\end{array}$ \\
\hline $\begin{array}{l}\text { Later } \mathrm{PCH} \\
\text { comanagement in new } \\
\text { political context } \\
(1995-2009)\end{array}$ & $\begin{array}{l}\text { Let the leaders pass articulated by } \\
\text { leaders, recommended to PCMB, and } \\
\text { instituted in Yukon. }\end{array}$ & $\begin{array}{l}\text { TEK embraced by board; used as } \\
\text { basis for addressing Dempster } \\
\text { disturbance concerns; later } \\
\text { challenged by indigenous hunters. }\end{array}$ & $\begin{array}{l}\text { State management highly responsive to } \\
\text { comanagement board recommendations }\end{array}$ \\
\hline
\end{tabular}

Padilla's research on caribou leaders and highway hunting provided a more contemporary account of events and perspectives during the final period when the let the leaders pass policy was enforced and then rejected. Interviews on caribou leaders and hunting were conducted in three First Nation communities in the Canadian Yukon and Northwest Territories that are among the primary users of Porcupine Caribou. They included Dawson City (population 1327), Fort McPherson (population 776), and Old Crow (population 253; Statistics Canada 2006). This research was conducted in partnership with the Tr'ondëk Hwëch'in First Nation based in Dawson City, Yukon Territory, the Tetlit Gwich'in Renewable Resource Council of Gwich'in First Nation, based in Fort McPherson, Northwest Territories, and the Vuntut Gwitchin First Nation, based in Old Crow, Yukon Territory. These three communities capture a wide spread in geographic location along the Porcupine Caribou migration and wintering range, the communities' involvement in issues related to Dempster Highway hunting, as well as their differing social-ecological characteristics, i.e., population or road access. Fort McPherson and Dawson hunters make extensive use of the Dempster Highway for accessing Porcupine Caribou, whereas Old Crow hunters primarily use river and snowmobile access, depending on the season. Fort McPherson hunters take the greatest number of caribou of all communities of Canada and Alaska that hunt Porcupine Caribou, and Old Crow harvests the highest number of caribou per capita of all communities (Kofinas 1998). Although Dawson harvests caribou, the community is more dependent on moose. Of the 29 interviews with PCH hunters and elders conducted during summer 2006, 9 were completed in Dawson City, 11 in Fort McPherson, and 9 in Old Crow. In each community we hired and worked with a local assistant, who worked with the local First Nation, or renewable resource council to select interviewees. All respondents from these communities were members of the local First Nation. Both younger and older hunters were selected to capture changing knowledge (Stevenson 1996) but also to capture a wider space/ time scale (Ferguson and Messier 1997). Local organizations advertised this study of caribou leaders for several weeks before our arrival to inform the community about the project. Local assistants contacted specific respondents informally to ask for their participation in interviews shortly before they were conducted. We interviewed 5 women and 24 men. Their ages ranged from 42 to 91 years of age, with 16 being elders. We called the rest of the respondents "younger hunters."

Interviews on caribou leaders and hunters were semistructured and most questions were open-ended to allow subjects the freedom to respond with detailed information and anecdotal personal accounts (Huntington 2000, Perecman and Curran 2006). Interviews were constructed around the assumption that traditional knowledge is rooted in local cultural contexts and arises from long-term interactions between people and resources (Folke 2004, Berkes 2008). We audio-recorded all interviews and transcribed their scripts entirely. We used HyperRESEARCH ${ }^{\mathrm{TM}}$ coding software for qualitative analysis and a content analysis protocol through open coding. Open coding provided the basis for arriving at categories of responses that were captured as quotes within each interview.

Together the research findings of the Kofinas and Padilla projects provided a uniquely rich source of evidence for understanding the historic and multiscale transactions associated with Dempster Highway caribou hunting and the nature of the failed let the leaders pass policy.

\section{Historical analysis of phases of management and identification of barriers}

Several research questions guided our identification and review of the four phases of caribou management. They include who managed for indigenous caribou hunting, what the management strategies were and their implementation, when, and for how long? Through extensive archival research and key informant 
Table 2. Sources of evidence.

\begin{tabular}{|c|c|c|}
\hline Source & Period or Date & Details \\
\hline $\begin{array}{l}\text { Participant observation in } \\
\text { comanagement process, including } \\
\text { observations of Porcupine Caribou } \\
\text { Management Board (PCMB) meetings }\end{array}$ & $\begin{array}{l}1992 \text { to } 1998 ; 2005 \\
2006\end{array}$ & $\begin{array}{l}\text { G. Kofinas lived in user communities for } 10 \text { months; attending meetings; } \\
\text { traveled with PCMB members, hunting on the Dempster Highway with local } \\
\text { residents, and participated in all workshops during the 1992-1998 period. } \\
\text { E. Padilla attended three PCMB meetings in addition to being in communities } \\
\text { during interviews. }\end{array}$ \\
\hline Focus group & March 1995 & 15 Fort McPherson hunters participated \\
\hline $\begin{array}{l}\text { Archival research on Dempster Highway } \\
\text { and Dempster Highway hunting }\end{array}$ & To 2004 & $\begin{array}{l}\text { Yukon and Northwest Territories (NWT) agency personnel provided access to } \\
\text { agency files; other searchers at Yukon Archives of Yukon College. }\end{array}$ \\
\hline $\begin{array}{l}\text { Interviews of caribou users on } \\
\text { comanagement }\end{array}$ & $1994-1996$ & 220 structured interviews completed and analyzed \\
\hline Coding of PCMB minutes & $\begin{array}{l}\text { From } 1986 \text { (first } \\
\text { PCMB meeting) to } \\
2007\end{array}$ & Coded thematically to capture issues and actions \\
\hline $\begin{array}{l}\text { Semistructured interviews with board } \\
\text { members, community leaders, and agency } \\
\text { personnel }\end{array}$ & 1994-1997; 2005 & 20 interviews completed, transcribed, coded. \\
\hline $\begin{array}{l}\text { Interviews with elders and caribou } \\
\text { hunters on caribou leaders and the "let } \\
\text { the leaders pass" rule }\end{array}$ & 2006 & $\begin{array}{l}29 \text { interviews completed with elders and hunters of Old Crow (9), Dawson (9), } \\
\text { and Fort McPherson (11). }\end{array}$ \\
\hline
\end{tabular}

interviews, we reconstructed historic events by reviewing printed media communications, accessing internal agency and board memos, and coding comanagement board minutes and other documentation. We describe the management strategy under which the let the leaders pass policy was implemented and why it was no longer enforced. Throughout the account, we describe the relevant interactions between different levels of government, communities, and hunters. This factual account served to illustrate the context that led to the struggle of interests between the comanagement body, government agencies, communities, resource users, and stakeholders' cultural values and management approaches.

We identified barriers by classifying conditions from the historical account under general themes, e.g., worldview aspects of traditional knowledge, problems of scale, institutional dynamics, social characteristics, etc., that we based on a review of a wide range of literature, including but not limited to writings on traditional knowledge and comanagement. We identified comments and themes from the formal interviews to illustrate the discussion. We then grouped these themes and conditions to generate aforementioned "barriers" specific to the case. We later shared these barriers with key respondents, and modified them based on their review. A detailed presentation of the interview analysis to identify caribou leaders can be found in Padilla (2010).

\section{RESULTS}

\section{Historical phases of Dempster Highway hunting issues and management}

Phase one: traditional hunting (precontact to 1950s) Slobodin (1962), McClellan (1987), Frank and Frank (1995), Kofinas (1998), and others have described the local system of caribou management for $\mathrm{PCH}$ user communities, including informal institutional arrangements shaping community decision making related to hunting. From precontact with westerners to the mid-1900s, hunting commonly occurred as community hunts under the direction of a chief or leader (Slobodin 1962). Before the adoption of the rifle, people used "caribou surrounds" or fences to direct herds into harvest areas, with family groups working cooperatively to achieve a successful hunt (Warbelow et al. 1975, Greer and LeBlanc 1992). Hunting caribou successfully was a matter of survival during precontact, demanding that the community members work cooperatively to intercept, kill, butcher, and distribute caribou meat. Old stories, as reported by Gwich'in elders, tell how caribou and people were one and the same during "the time before there was time," and after separation, caribou gave themselves to hunters as gifts, with each partner fulfilling a set of obligations to care for the other (Slobodin 1981, Kofinas 1998). From these understandings of human-environment relations derived norms for respectful behavior toward animals such as proper methods of hunting, obligations of sharing the harvest with others, and sanctions against disrespect or wastage of meat (Sherry and Vuntut Gwitchin First Nation 1999). Many of those traditional principles of conduct for hunting are present today in the worldview and behavior of indigenous PCH users. Elders interviewed in this study spoke of the traditional harvesting method as a model for good hunting and compared it to the less structured modern hunting:

Around fifties before that, you, well people used to move you see, and I seen it too, because when you move, there was one guy, chief, always one guy that talked in the morning, you don't just go out there, you can't. So the guy that's in charge, and this is really morning too, as soon as you get up after dark, you got to get up. And he tell you got to go this way today, you go this way and you go there. Sometime when there's lots of people, another bunch go there. If you see caribou you don't just shoot it, have to come back, caribou going to come back. The herd. So the next day, you start planning that night. Next day you go there and everybody hunt, that's way you do it you don't just go hunting. ... Should be certain time you go up on the highway. There's people with every truck. Should be one boss, and then there wouldn't be a problem. (Fort McPherson respondent) 


\begin{abstract}
We had one boss that we go out hunting, we all gather together and the oldest guys told us what to do, you go there, you go there, you go there so everybody knows who's here who's there. That's the way we used to do it.... We used to have, circle around the caribou. Now you just go up and help yourself, and don't have to wait for nobody. (Old Crow respondent)
\end{abstract}

Beginning in the late 1950s through the 1970s, there was a significant change in the social organization of traditional caribou hunting because the introduction of new harvesting technologies, i.e., snowmobile and automobile, mostly replaced hunting by foot, snowshoe, and dog sled. A hunter described the change from traditional hunting and spending considerable time on the land to the practice of using trucks for shorter hunts:

People never used to hunt in town like this, like nowadays; they were gone for couple weeks sometime, a month, they just live out there. Nowadays they hunt with trucks they don't even skin caribou up, they bring them back like that. Nowadays the generation is different from long ago, way different, way, way different. More modern than long ago.

(Fort McPherson respondent)

The traditional organization of hunting caribou described by these elders illustrates how leadership and social controls on hunting behavior were linked and coordinated. Caribou hunting later became a more individualized activity. Although small group hunts are still common, the community hunt under the leadership of a skilled "boss" became an anomalous means of harvesting, and the role of the hunting leader in overseeing group hunting mostly disappeared.

Phase two: precomanagement: Dempster Highway construction to completion and signing of the Canadian PCMA (1960s-1985) In 1959 Canada's Prime Minister John Diefenbaker announced the construction of the "the road to resources," which would connect southern Yukon Territory with anticipated hydrocarbon development activities in the Mackenzie Delta region of Northwest Territories. Completed in 1979, the portion of the Dempster highway at the Yukon Territory-Northwest Territories border linked the Yukon Territory community of Dawson City to the Northwest Territories communities of Fort McPherson, Tsiigehtchik (formerly Arctic Red River), and Inuvik.

The indirect effects of the highway and hunting on the highway posed the greatest concern. Early scientific studies investigated the impact of the highway and traffic on caribou migration, but found little to no evidence of disturbance (Dempster Highway Working Group 1978). In contrast, a panel of biologists convened by the Canadian Federal Government predicted that increased access and hunting from the Dempster Highway would reduce PCH size by 30 to $40 \%$ (Alaska Highway Pipeline Panel 1979). Articles from the local media in the mid to late 1970s also warned of the impact of Dempster Highway hunting on caribou, with headlines such as "Highway could deplete herd" (Fraser 1976) or suggestions such as "Improper management of the area could result in the herd's extinction, according to many experts" (Renaud 1978). The concerns regarding the future of the PCH were also elevated to a national and international level through the highly publicized Mackenzie Valley environmental impact assessment chaired by Judge Thomas Berger ("The Berger
Inquiry"). The impact assessment and its community hearings captured the attention of many Canadians and brought a heightened awareness of the $\mathrm{PCH}$ and the potential impacts of Dempster Highway hunting (Berger 1977).

Lack of consultation with indigenous hunters characterized pre comanagement. For example, the Chief of Fort McPherson during the final construction phase of the highway reported to Kofinas that his community only learned about the plans for highway construction indirectly. When the community's leadership was told by government that the highway would be constructed, it stated that it would be "giving the people a road." He and other elders in the community reported that most people in the community had little idea of the implications of a road and community leadership had no say in its construction or routing.

Until 1985, the territorial government of the Yukon Territory was responsible for regulating hunting and based wildlife management decisions primarily on scientific studies (McCandless 1985). The paradigm of state-controlled wildlife management and the dismissal of indigenous knowledge was evident in internal Yukon government memorandums between the director and assistant director of wildlife (18 July 1977: Appendix 2, 6 July 1978: Appendix 3). In 1978, the Yukon Government's Department of Renewable Resources formed a Dempster Highway committee to assist in coordination of the $\mathrm{PCH}$ management. Its jurisdiction only extended to nonindigenous hunters, unless the species was declared as endangered. A particular focus of the committee was finding ways to limit indigenous hunting because these users constituted the majority of caribou harvesters.

The absence of recognized rights by indigenous $\mathrm{PCH}$ hunters was discussed by top Yukon government officials, with the Yukon Government Assistant Director of Wildlife (18 July 1977) questioning whether indigenous people should be given special rights to hunt caribou and not recognizing the need to hunt caribou as critical to survival in contemporary times:

Perhaps the question of Native hunting rights could be
evaluated. Inmyopinion, there is no dependence anymore
on caribou to survive. If caribou are not shot because they
don't come close to a community, meat is being made
available through other means. In light of this, I question
the philosophy that this herd should be managed
primarily for Native use and to perpetuate traditional
lifestyle. (Appendix 2)

Indigenous hunters shifted their perspective about whether formal regulations were applicable to them. After an abnormal calving year reported in 1977, continued predictions of a declining population sensitive to subtle increases in harvest, and observations of changes in the migration route, biologists urged for a closure of the road to hunting (18 January 1978: Appendix 4, 17 June 1977: Appendix 5). Their recommendations to government led to establishment of a $16 \mathrm{~km}$ no-hunting corridor along the highway (1978). The restrictive corridor had the desired impact as hunting dramatically decreased in subsequent years, partly through compliance of indigenous hunters who perceived that the regulation superseded constitutionally based aboriginal hunting rights. However, from 1981, the general perception changed to view the corridor hunting restrictions as legally not 
applicable to indigenous people, and caribou hunting from the Dempster Highway again increased in the Fort McPherson area. The hunting corridor was then decreased to $2 \mathrm{~km}$, causing indigenous harvest in the southern portion of the Dempster Highway to increase. These multiple changes in no-hunting corridor policy were the first of continuous changes in hunting management from then onward.

Preferential consideration for opinions voiced by residents of Old Crow, an off-road community that is highly dependent on $\mathrm{PCH}$, may have set the stage for increased intercommunity conflict through new efforts at range-wide caribou management. Residents of Old Crow echoed biologists' concerns over hunting caribou on the highway. Old Crow's location in Yukon Territory gave it a political advantage over non-Yukon $\mathrm{PCH}$ user communities, such as Fort McPherson. Government agencies perceived communities in Yukon Territory as having little to no impact on the caribou population because of their smaller human population and more traditional style of harvesting, i.e., not road hunting, as evidenced in internal agency memoranda (Appendix 6). The commissioner to the Yukon Territory, head of the government at that time, along with other government officials, sided with Old Crow community concerns in a memorandum to the Chairman of the Council for Yukon Indians (8 March 1977), stating "We believe that the general consensus in Old Crow is that all hunting [from the Dempster Highway] be stopped and it is our conviction that these people [Vuntut Gwitchin of Old Crow] are most closely tied to the Porcupine Caribou population" (Appendix A.1). In contrast, increasingly publicized issues of unethical hunting and stories of caribou slaughter by Fort McPherson hunters in the media tainted the image of Northwest Territories hunters throughout the 1980s. Decades later, some residents of Yukon communities still hold this perception.

The Berger Inquiry and others suggested that regional solutions to PCH management be considered. In 1983, a wildlife advisory committee meeting proposed a range-wide management plan to increase cooperation with indigenous hunters and establish harvest quotas. After years of negotiation, Yukon Territorial Government, the Government of NWT, and First Nations of the region (Peter and Urquhart 1991, Kofinas 1998) signed the formal Porcupine Caribou Management Agreement (PCMA) in 1985. The Canadian PCMA, like other formal comanagement agreements of its time, was signed to provide shared authority between indigenous user groups and government agencies in decision making (Houde 2007, Pinkerton 1989, Armitage et al. 2007, Kofinas 2009). As a part of the agreement, the PCMB was established.

\section{Phase three: caribou comanagement through the PCMB}

(1985-1995)

One of the PCMB's primary goals, as stated in the agreement, is to "cooperatively manage to ensure conservation of the $\mathrm{PCH}$ with the view to ensure continued subsistence usage" (PCMA 1985). According to government negotiators of the agreement, the PCMB was established in large part to address the Dempster Highway hunting management issue (Government of Canada et al. 1985, Kofinas 1998, Kofinas et al. 2000), and created during a period of wildlife management devolution across the North (Usher 1986). With its representatives of First Nations of Yukon Territory and Northwest Territories, the Inuvialuit, nonindigenous users, two territorial governments, and federal government, the comanagement board grappled with problems associated with the Dempster Highway from the time of the board's inception. Since the Canadian Porcupine Caribou comanagement arrangement was established, conflicts between government agencies and communities reduced. However, Yukon communities, perceived as "more traditional" and having low impact on the $\mathrm{PCH}$, and Northwest Territories communities on the highway perceived as hunting unethically, became increasingly polarized. Intercommunity conflicts about Dempster Highway hunting increased as groups sought to jointly manage caribou hunting.

Cumulative impacts on caribou migration of human activities along roads continued to be of concern to scientists (Wolfe et al. 2000). However, the $\mathrm{PCH}$ had not suffered the drastic decline predicted in 1979, despite highway hunting. Instead the herd grew until its population peaked in 1989 with 178,000 caribou (PCMB 2010). Population-level effects related to hunting were supplanted with the greater concern on displacement of caribou from winter grounds due to highway hunting disturbance (PCMB 1995, 2000, 2006, 2007, Smith and Cooley 2003).

Hunter education efforts at the local level brought only limited success. An original member of the PCMB, who was also an elder and the traditional chief of Fort McPherson, took a leading role in addressing unethical Dempster Highway hunting at the local level by patrolling the highway, talking with hunters, and cleaning unsightly kill sites. The effectiveness of his efforts in the new context of post-traditional, individualistic highway hunting was, however, self-reported as limited (phase three). In addition to these initiatives, the PCMB also produced and distributed a video on the problems of Dempster Highway hunting to residents of local user communities, in an effort to increase public awareness and find a solution.

Since the PCMB's creation, recommendations for addressing Dempster Highway issues have sought to strike a balance between hunter compliance, representation of traditional knowledge, and protection of the caribou herd, producing several modifications in formal policy. Two major sets of recommendations were implemented by the Yukon Government and enforced on indigenous hunters in 1990. Snow machine, i.e. snowmobile, access was permitted for indigenous hunters beginning 1 November, and a $2 \mathrm{~km}$ no-hunting corridor was implemented. In spite of ongoing efforts to address Dempster Highway issues, conflict over unethical hunting practices and lack of consensus among indigenous hunters persisted.

\section{Phase four: comanaging caribou hunting with traditional} knowledge in a new political context (1995-2009)

The "let the leaders pass" proposal came forward in 1995, at a time when the idea of integrating TEK with the comanagement was gaining international popularity as a solution for complex resource management problems (Berkes 1993, Inglis 1993, Stevenson 1996). After local deliberations by community elders, hunters, and leaders, the Tetlit Gwich'in Renewable Resource Council, i.e., local renewable resource council of Fort McPherson, sent a representative to the $\mathrm{PCMB}$ at its spring meeting, requesting that the board implement a closure of highway hunting upon the first arrival of caribou each fall. The local council representative explained that the basis of the proposed closure was his elders' traditional knowledge of not disturbing leaders of the caribou 
herd during its migration. This reference was the first time some nonindigenous members of the board had heard of the traditional rule, which generated backstage discussions among those board members about the significance of making policy based on TEK not backed by science.

As a follow up later in 1995, the PCMB organized a "Dempster Highway Workshop" with Fort McPherson hunters and elders and government employed resource managers. The workshop report noted that because science-based wildlife studies on caribou leaders and Dempster Highway impacts on herd migrations were both costly and not available, the TEK of indigenous elders should therefore be used as the basis of decision making (PCMB 1995). At a subsequent meeting, the PCMB endorsed the Tetlit Gwich'in Renewable Resource Council's alternative management approach and recommended the let the leaders pass closure to government ministers. The Yukon Territory Government, in turn, put the closure into law. The oneweek hunting closure was initially applied to the entire length of the Dempster Highway and later separated into two different closure periods to correspond with different north and south migration timing (PCMB 2006). The PCMB and the partner management agencies had hoped the let the leaders pass regulation would be embraced by local hunters because it was conveyed to the board as a traditional practice. The formal regulation was formulated as a one-week closure, with dates determined to match the time when caribou first migrate near the highway and ensure the caribou leaders would have time to pass.

Local perspectives on the number, sex, and ages of caribou leaders needed to let the leaders pass, however, was not well defined (Smith and Cooley 2003, Padilla 2010). In interviews local hunters expressed differing opinions about the idea of a closure, with some recommending a longer closure, of up to a month long, while others preferred to use individual judgment as to whether leaders had already passed and not be subjected to a closure (Padilla 2010). In addition, in a 2006 review of Dempster Highway regulations initiated by the PCMB, the Yukon Minister of Environment received mixed support from affected Yukon Territory and Inuvialuit communities for a proposed second hunting closure (PCMB 2007).

During the 22-24 September 2007 PCMB meeting, the PCMB Chair noted that honoring elders' concern for protecting caribou leaders was a priority. The PCMB emphasized the notion of respectful hunting in its media and education outreach (See Fig. 1). Interviews with elders and hunters suggested intergenerational differences in perceptions, with elders expressing dissatisfaction over modern hunting practices, while younger hunters reported that they hunted according to their elders' teachings.

Despite general support for the regulation, the actions of one First Nation resident from one community challenged and ultimately discontinued the regionally implemented regulation. In September 2007, a "stay of proceedings" against a Tr'ondëk Hwëch'in (Dawson) First Nation's member ended enforcement of the one-week closure to let the leaders pass. This younger hunter who violated the hunting closure was charged by wildlife officers and announced his intent to contest his case in court. During the interview we conducted with him, he explained his dissatisfaction with the regulation as an infringement on his indigenous hunting rights, asserting that consultation done to formulate the new regulation did not adequately recognize traditional knowledge of his Dawson First Nation members. Out of nine elders and hunters we interviewed in Dawson, three hunters said that the hunting closure did not match their elders' teachings, and another four elders and hunters were in partial disagreement with letting the leaders pass. Based on these interviews and informal discussions with PCMB representatives, there was at least partial support for this Dawson member's case in the community. After assessing the likelihood of successfully defending the new regulation and before the case went to court, the Canadian Department of Justice recommended a "voluntary compliance" approach, rather than enforcement of a formal hunting regulation. In September 2007, the Yukon Territory Minister of Environment announced to the PCMB they would not enforce the one-week closure and the no-hunting corridor until further consultation established consensus between all affected parties.

Fig. 1. Cartoon used by the Porcupine Caribou Management Board (PCMB) to illustrate the "Let the leaders pass" hunting regulation. Cartoon by D. Urquart, who served as the PCMB Secretary at that time.

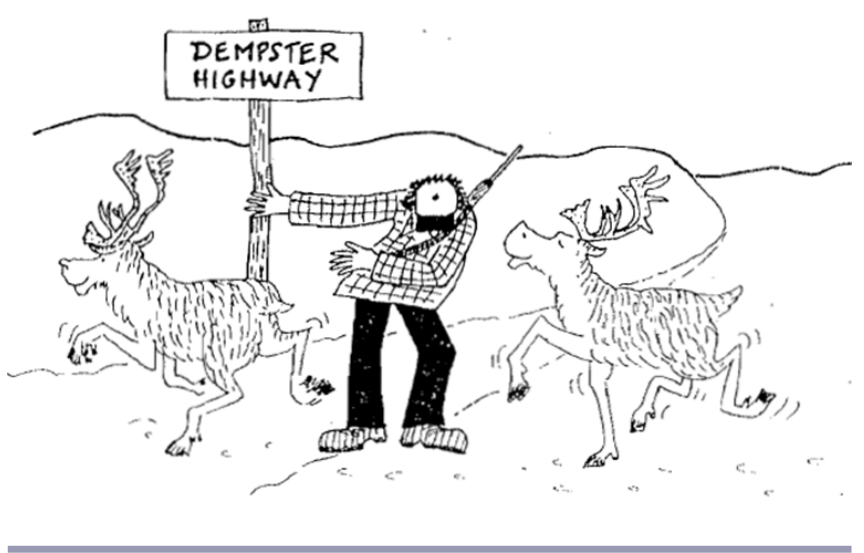

The political context changed dramatically after land claims agreements in Yukon and Northwest Territories were signed in the 1980s and 1990s, which added to an intercommunity political dynamic of First Nations autonomy. Although Northwest Territories communities fell under the land claims agreements for Gwich'in of NWT in 1992 (Government of Canada and the Gwich'in Tribal Council 1992), and the Inuvialuit Final Agreement in 1984, the Yukon First Nations negotiated and signed the Umbrella Final Agreement under the Council for Yukon Indians in 1993 (Government of Canada et al. 1993). Unlike the Northwest Territories land claims agreements, the Yukon agreement allowed self-government and regulatory organizations under separate First Nation agreements for each community. Eleven First Nations of Yukon signed Individual Land Claims and Self-Government agreements from 1995 to 2006. Each First Nation of Yukon was concurrently engaging in regional policy making while at the same time asserting its political autonomy.

The let the leaders pass initiative sharply contrasted the approach used by regional governments before the comanagement board 
was created. It was less top-down and less restrictive for hunters compared to the loss of indigenous hunting rights envisioned by some government agency officials of the pre-PCMB period. However, enforcement of the TEK-based rule was superseded by an assertion of an individual's right to hunt and was discontinued.

During the September 2007 meeting, the PCMB discussed the legal challenges that had undermined the formal let the leaders pass regulation in Yukon Territory and endorsed voluntary compliance. This shift suggested that emergence of greater First Nations' political autonomy would necessitate in a new role for the comanagement organizations in the future, focusing more on facilitation rather than making recommendations about specific regulations from the board to government ministers. In subsequent efforts to develop a harvest management strategy, the PCMB strived to put a greater emphasis on achieving full consensus of parties (PCMB 2010).

\section{DISCUSSION}

\section{Barriers in using TEK-based hunting regulations in comanagement}

The efforts of the PCMB to experiment and learn from its experience with the Dempster Highway hunting issues demonstrate how comanagement is a process of trial and error problem solving, and how in the process of integrating knowledge systems in comanagement, the use of TEK can encounter significant barriers. Although comanagement in some cases brings scientists, locals, and managers together for shared decision making (Osherenko 1988, Armitage et al. 2007, Berkes and Berkes 2009), combining knowledge systems is a challenging practice (Kofinas 2005, Nadasdy 2003b, Natcher et al. 2005, Clark et al. 2010, Berkes 2012). We identify barriers that prevented the lasting implementation of a traditional knowledge-based regulation. This list of barriers is not all-inclusive and some of their elements overlap, but we argue they are the most important and their identification and study may help to inform future comanagement enterprises in becoming more effective.

\section{The context-specific nature of TEK limits its application in resource management regulations}

TEK and traditional hunting practice are not only concerned with facts and observations about the environment, but also with how people relate to each other, and how they should behave in society and their environment (Collings 1997, Natcher et al. 2005, Berkes 2012). Conventional resource management has in some cases failed to recognize the social, cultural, and worldview dimensions of TEK (Nadasdy 1999, 2007, Natcher et al. 2005). The concept of caribou leaders likely arose based on hunters' long-term observations to ensure the availability of caribou to harvest and increase chances of human survival. In addition, the notion of letting caribou leaders pass is part of the human-environment relations derived norms for respectful hunting behavior, central to the worldview of PCH indigenous hunters (see phase one).

The different components of TEK, such as social norms and spiritual aspects, cannot be separated from what is perceived as "factual" information, as it strips TEK of its meaning (Wilson 1996, Cruikshank 1998, Houde 2007). The literature shows that TEK is locally restrictive and in most cases does not apply outside of that locality (Antweiler 1998, Cruikshank 1998). For example
Cruikshank's (1998) study of oral traditions illustrated how elders' stories and the knowledge they convey are highly individual. Moreover, TEK directly relates to resource use practice, and can vary widely between social groups, time, and place (Berkes et al. 2000). As explained in phase four, interviews with Dawson hunters indicated a perception that the formal oneweek closure regulation poorly matched the traditional notion of caribou leaders because it was not practical in the new context of highway hunting. Investigating the traditional meaning of caribou leader through interviews with elders and hunters, we found that caribou leaders, a highly context-dependent term, were described through individual hunting experiences, in the context of traditional community hunts, and on a local scale, varying with time in caribou migration, location, ecological context, political context, and hunting experience, including the status of the person interviewed (Padilla 2010). With such varying concepts of caribou leaders, it was challenging to create one locally endorsed and cohesive regulation across a vast region (Smith and Cooley 2003). The following respondents perceive differences in traditional knowledge practice and education between indigenous hunters in the Porcupine Herd region.

You can't paint every First Nation with the same brush. This First Nation here, it'll say it is very good. We've got no one around here that hunts like that. (Dawson respondent)

People you interview, they will probably interview different from me because we learn from our people, sometime our dad, our grandfather. I go in the mountain with them and they tell story about animals and I do something, I shoot caribou. (Fort McPherson respondent)

For some community members, the regulation appeared inconsistent with the stories they heard from their elders or their personal experience hunting caribou. Moreover, the regulation was an oversimplification and generalization of knowledge that is complex and situational. The worldview, variability, context dependence on local elders, and experiences caused a regional one-size fits all regulation like the one-week closure to be contested. The one-week closure did not address local and individual variations and social norms related to traditional knowledge of the let the leaders pass concept. However, the context-specific aspects of TEK alone did not preclude its use for management, rather social context, political issues, and an institutional misfit prevented it.

Changes in traditional authority systems, hunting technology, and the social organization of harvesting caribou affect the

effectiveness of TEK approaches in a contemporary social setting Hunting practice has become more individualistic (Barnhardt 2005). Feldman (1997) suggests that traditional communityoriented authority systems have eroded. Elders interviewed echoed this assertion in terms of caribou hunting because there is no longer "one boss" organizing community hunts (phase one) and dissatisfaction among elders is ongoing because of unethical hunting within communities (phase four). Elders explain how the let the leaders pass rule was applied and respected under the traditional hunting authority system. Similar accounts tell how the collective caribou hunt was well coordinated with individuals having specific roles (Bali and Kofinas 2008). Today, PCH hunters are not always subject to the judgment of their peers or the oversight of elders during hunts when carried out alone. The local 
initiative of the Fort McPherson traditional leader to address highway hunting issues proved to be limited in addressing problems with highway hunting (phase three). Hunters also have easier and faster access to caribou with trucks and all-terrain vehicles along the highway. The shorter, individual hunts, less oversight by traditional leaders, and easier access to caribou make up the modern hunting context.

Let the leaders pass TEK was incorporated into management outside of its traditional enforcement context, community-led hunts. TEK inspired the let the leaders pass policy in the context of adapting to modern hunting. It was not enforced in the context of social hunts, nor was it applied in the context of ensuring people's immediate survival. Letting leaders pass was traditionally used to ensure harvest by letting caribou settle in an area. The one-week closure to let the leaders pass was concerned with conservation of the $\mathrm{PCH}$ and an effort by elders to promote ethical hunting, whereas maximizing harvest was not central to the policy (although letting caribou settle in the area may lead to higher harvest).

We argue that the modern hunting context created a barrier to applying the traditional notion of letting leaders pass. Unlike the traditional use of letting leaders pass, the formal agency enforceable regulation was not highly flexible, because the oneweek closure did not call for hunters' judgment during every hunt as to which caribou are the leaders of the herd. Indigenous hunters rely on TEK to guide their own hunts and decide during the hunt whether leaders have passed. At the same time, the effectiveness of elders' informal enforcement of letting leaders pass at a broad scale is limited because of the modern individual hunting context. In addition, the government agency is limited with First Nation rights through land claims. Thus, a formal regulation, even if based on TEK, is insufficient to ensure broad compliance with management plans or ethical hunting practice.

The Yukon Government, following the recommendation of the PCMB, has modified Dempster hunting regulations several times, fine-tuning them and trying to identify robust policies that would accommodate all user groups (Table 2). Agrawal (1995) argued that TEK is ever changing, similarly to science, and thus not conserved indefinitely. TEK has two faces, one concerned with ancestral practice and another concerned with adaptation to the present and future (Berkes et al. 2000). TEK is therefore not bound to the past, but is rooted in ancestral practices while incorporating aspects of modern societies (Stevenson 1996). The revival of letting the leaders pass by local elders and the efforts to apply the concept through the PCMB management process show that TEK is adapting to modern hunting. Although the hunting closure to let the leaders pass did not last as an enforceable regulation, the renewed awareness of applying the traditional concept to highway hunting can be considered one step in the learning process.

Indigenous efforts toward self-government and political autonomy limit regional comanagement consensus in a heterogeneous cultural landscape

In the regulatory regime during this research, First Nation members have an indigenous right to hunt Porcupine Caribou, unless there is a conservation issue (Government of the Yukon Territory 2002). Collings (1997) argued that if political autonomy overrides resource availability concerns, there will be a lack of consensus among users. A single Dawson First Nation hunter legally challenged the no-hunting closure to let the leaders pass on the basis of inconsistency with his individual aboriginal right, based on the Tr'ondëk Hwëch'in (Dawson) First Nation land claims agreement (PCMB 2007). The First Nation agreement of Tr'ondëk Hwëch'in First Nation, signed in 1998 and after other agreements were signed and implemented, may help explain this First Nation's high interest to assert political autonomy and counter the formal closure to let caribou leaders pass.

In the past, the Canadian PCMB enabled recognition of indigenous people's hunting rights and rights in wildlife management through the communications and recommendations of the PCMB. However, in the new context of settled land claims agreements and First Nations seeking to exercise their powers, there existed an institutional mismatch of the PCMB and the emerging indigenous self-governments. In the case of the let the leaders pass discontinuation, formal recognition of a First Nation through its land claims agreement enabled an individual to defend his indigenous hunting rights where a conflict arose with a PCMB recommendation. Dawson First Nation perceived Dempster Highway hunting regulations imposed by Yukon Territory Government to interfere with its recently acquired political and cultural autonomy through self-government.

Adding to the barrier associated with greater political autonomy is the representation problem in northern comanagement, which is well documented in other studies (Kofinas 1998, Kruse et al. 1998). The representation problem results from board members who typically do not view themselves as speaking for their communities or First Nations and thus, First Nations in turn do not feel represented by the comanagement board. This creates a communication disconnect in conveying the political position of First Nations during deliberations at board meetings.

Intercommunity conflict in the context of Dempster Highway hunting, in addition to an intergenerational divide between elders and younger hunters within communities, contributed to noncompliance and members challenging the regulation. Elders in interviews expressed concern for younger generations' poor hunting ethics. Fort McPherson hunters historically received a bad reputation for highway hunting practices, whereas Old Crow hunters were most highly regarded as having retained their traditional practice. An effort resulted on the part of elders across communities to promote traditional hunting practices, with a focus on the Dempster Highway. Although younger hunters reported hunting according to elders' teachings, they were concerned with defending their individual indigenous rights in the face of government regulations. The historical context helps explain this perspective. After the construction of the Dempster Highway, the focus of managers was to limit indigenous hunting along the highway. Although indigenous hunters became part of the management process with the PCMB, some hunters were still cautious of formal management limiting their rights. When elders worked with the PCMB to create the hunting closure to let leaders pass, it was perceived by some younger hunters as an additional limitation on their indigenous rights, limiting also their ability to make the call when it comes to letting caribou leaders pass. Elders' efforts to improve younger generations' hunting practices was challenged by younger generations' desire to affirm their indigenous rights and perceived own good hunting practices.

Through land claims agreements, First Nation members were empowered to become managers, yet formal regulations recommended through comanagement still distinguishes users 
from managers. The power of individuals to challenge decisions made through the comanagement process decreases the potential for durable formal regulations and compliance. Consequently, users may perceive the comanagement board as less valuable to advancing individual rights (Usher 1993). Although TEK-based information may vary depending on the purpose and interests it serves, it is not neutral and can be used for political objectives (Wavey 1993, Agrawal 1995). PCMB management based solely on TEK exacerbated existing community-to-community conflict where there was a struggle between political autonomy and restrictive formal regulations viewed by the board as for the common good. In the following quote, a Dawson hunter forecasted the issue of compliance and intercommunity conflict.

Don't attack a person that doesn't go under YTG [ Yukon Territory Government ] law, because like I said, it's going to lead into Indian wars. Which is beginning now, it's going to come. (Dawson respondent)

The use of formal TEK-only based regulation exposed local and regional heterogeneity of rules on caribou hunting. Ostrom (1990) found that the absence of locally derived rules and enforcement, such as lack of explicit recognition of land claims agreements and unwillingness to recognize the legitimacy of diverging interests in a heterogeneous region are institutional weaknesses that can lead to institutional failure and ecological and social degradation. The need for explicit recognition of locally specific indigenous rights and government through land claims agreements created an additional barrier because indigenous people are not homogenous in their traditional hunting practices. As a result, hunters resisted and contested regulations and enforcement that limited indigenous rights in the context of efforts toward political autonomy.

The mismatch of agency enforcement of hunting regulations and TEK-based education is problematic

Elders started all interviews by talking about respectful hunting according to traditional values and their own elders' teachings. These respondents blamed the lack of good hunting practice on the absence of traditional education, not a shortage of regulation enforcement.

Well what I think is sad, nobody teaching anybody, that's why they go up there and just shoot. Just one but you can't handle. There is no teaching going on. Well, all these things is ours, not for you, not for the government, it's our people doing that, it's up to us, see you can't fix it.... But you have to teach them skin caribou and stuff like that, and we're not doing that, it's our fault. Can't blame the younger people with it, it's our fault; we're not doing it. Elders supposed to tell chief what to do, not him. (Fort McPherson respondent)

Although some have argued that traditional knowledge is not compromised and still fully practiced with younger generations (e.g., Sherry and Myers 2002), others argue that older elders are the only members of the society left with the "original" traditional knowledge (Davis and Wagner 2003). As Barnhardt (2005) noted, researchers prefer capturing the knowledge of elders because the knowledge of younger generations is regarded as eroded. The PCMB likewise relied on elders' knowledge of caribou leaders to derive a widely applicable highway hunting regulation. Padilla (2010) found that elders' descriptions of caribou leaders were richer when compared with younger hunters' versions. However, the ecological knowledge of elders varied locally (Padilla 2010). Younger Dawson First Nation hunters in our interviews perceived the one-week closure as mismatched with their own elders' teachings, and therefore did not recognize it as legitimate.

The focus on enforcing this regulation regionally may have overshadowed the educational potential of letting the leaders pass. Some argue that conservation laws erode the social power of elders and place elders in an inferior social position (Phuthengo and Chanda 2004). Moller et al. (2004) emphasized the use of traditional knowledge as an educational tool to promote sustainable harvest, and not produce prohibiting laws. Likewise, some authors caution against regulating based on TEK, and focus on gathering information and educating (Wavey 1993, FernandezGimenez et al. 2008). During the PCMB Dempster Highway Workshop (1996), elders urged for revival of traditional hunting practices. Elders interviewed for this study warned that the younger generation is no longer following traditional knowledge and practices properly. Elders thus pushed for the let the leaders pass concept to ensure continued availability of caribou, but also to bring youth back to traditional ways, addressing both conservation and social goals. This rationale and strategy emphasized the social role of elders as educators.

Elders are considered the best educators for hunting because they have the most knowledge acquired throughout their lifetime (Hart 1995). Fernandez-Gimenez et al. (2008) suggested that elders favor education over formalized hunting rules. Educating youth about TEK or traditional hunting practices, however, does not necessarily match modern practices but emphasizes values that were continually important to people's survival in the past (Barnhardt 2005). The effort to bring the let the leaders pass rule to the forefront of management discussions was an educational effort. Elders hoped to improve hunting practice along the highway. They addressed concerns of keeping caribou in the area/ avoid deflecting the herd from wintering grounds. In our interviews, $83 \%$ of the respondents agreed that caribou leaders existed and described them according to hunting practice (Padilla 2010). However, the formal hunting closure was not well received by all indigenous hunters. The hunter interviewed below describes the confusing aspect of managing resource use through comanagement boards and government-initiated regulations rather than elders' education.
Natives use common sense, common knowledge, if they think and speak from their heart, they'll never have a problem. If you start speaking from your head in these boards and committees out there, governments, and pretty soon you're all mixed up and you don't even know what the decision is anymore. But if they think about it, go back to their elders, and these kids are smart now, in both worlds, I think they can take anybody on. (Dawson respondent)

Although the one-week closure was primarily based on a broad definition of caribou leaders derived from elders' knowledge, it did not actively engage elders in implementing the let the leaders pass rule locally. Thus, elders blamed poor hunting practices along the Dempster Highway on the lack of education, while management focused on enforcement of the let the leaders pass regulation. 


\section{CONCLUSION}

The case of regulating for letting the leaders pass policy illustrated how the use of TEK, like science-based management of an earlier era, interfered with subsistence hunting and created a level of intercommunity conflict, lack of compliance, and no long-term solution to a specific wildlife management concern. The one-week closure did not address local and individual variations and social norms aspects of the let the leaders pass concept. Some hunters perceived Dempster Highway hunting regulations imposed by Yukon Territory Government to interfere with recently acquired political autonomy through self-government.

Based on the findings of this case study, we make the following suggestions for future comanagement. Firstly, comanagers should be attentive to the differences in informal customary hunting traditions and formal rules that carry the force of law. Comanagers also need to ensure that recommendations generated by a comanagement board have the full support of stakeholders that share authority in resource governance. Where there is limited consensus, more consultation may be needed before regulatory actions are taken. This suggestion also comes with the acknowledgement that protracted conflict and inaction over a long period may in some cases threaten the ecological sustainability of a resource. Moreover, comanagers should find ways of supporting the role of elders in education and oversight of hunting activities. Finally, all parties should hold open discussions about the similarities and differences in their perspectives on traditional hunting practices, e.g., what is a caribou leader, to avoid or at least recognize conceptual ambiguity.

Hunters and wildlife managers perceived a dual benefit of the let the leaders pass policy: (1) ensuring availability to caribou by hunters, and (2) minimizing disturbance to herd migration, as well as promoting maximum use of the winter range by caribou. Ironically, an unintended consequence of letting leaders pass may be an increase in total harvest levels. Although deflecting caribou could lower harvest, other issues such as population effects of selectively eliminating leaders could also be problematic (Padilla 2010).

Although at some levels the implementation of the TEK-based regulation through comanagement can be viewed as a failure, it can also be understood as one step in an on-going social learning process of experimentation and adjustment based on experience. What appears to be a failure to find a workable solution to Dempster Highway hunting issues throughout the PCMB's history is at least in part the result of social-ecological change and an effort to adapt through the comanagement process. Indeed, wildlife management approaches need to be flexible, allowing for changes in strategies to reflect the ever-changing and adapting qualities of TEK and the social conditions in which they are embedded. The PCMB has encountered many challenges to its proposed strategies over the years. Nevertheless, the organization has succeeded in experimenting with new recommendations, learning from its experience, and moving on to implement new strategies, including rethinking its core functions as a comanagement board. The barriers to letting the leaders pass should be seen as a door to adaptation and innovation for more effective future management of hunting on the Dempster Highway.
Responses to this article can be read online at: http://www.ecologyandsociety.org/issues/responses. php/5999

\section{Acknowledgments:}

We thank members of the Porcupine Caribou Management Board who informed our study of Dempster caribou hunting management; those interviewed, including Neil Colin, Art Christiansen, Woodie Elias, Amos Francis, Donald Frost, Percy Henry, Ronald Johnson, Angie Joseph-Rear, Roberta Joseph, Peter Josie, David Harvey Kassi, Danny Kassi, Peter Kay, Peggy Kormendy, Irwin Linklater, Peter Nagano, Robert Rear, William Teya, Wanda Pascal, Abraham Stuart, Abraham Peterson, Michael J. Pascal, Ernest Vittrekwa, Joel Peter, Randall Tetlichi, Peter Tizha, George S Moses, and others who did not wish to be mentioned; to May and James André, Cheryl Charlie, James McDonald, and Ryan Peterson who assisted in interviews; to Joe Tetlichi and family for hosting Elisabeth in Old Crow; and to Gregory Finstad, Brad Griffith, Archana Bali, and Naomi $O^{\prime}$ Neil for comments on various editions of the manuscript. This project was supported by the Porcupine Caribou Management Board, Vuntut Gwitchin First Nation, Tetlit Gwich'in First Nation, Tr'ondëk Hwëch' in First Nation, Yukon Government, the Resilience and Adaptation Program at the University of Alaska Fairbanks, the U.S. National Science Foundation (OPP Project \#0531200) Heterogeneity and Resilience of Human-Rangifer Systems: A Circumpolar Social-Ecological Synthesis Project), and the Institute for Global Awareness. We also thank Nancy Tarnai for reading the manuscript. The ideas and opinions expressed in this paper are those of the authors and not the funders.

\section{LITERATURE CITED}

Agrawal, A. 1995. Dismantling the divide between indigenous and scientific knowledge. Development and Change 26:413-439.

Alaska Department of Fish and Game. 2005. Western Arctic caribou trails 7. Alaska Department of Fish and Game, Division of Wildlife Conservation, Juneau, Alaska, USA.

Alaska Highway Pipeline Panel. 1979. Initial impact assessment: Dempster corridor. Alaska Highway Pipeline Panel, Winnipeg, Manitoba, Canada.

Antweiler, C. 1998. Local knowledge and local knowing: an anthropological analysis of a contested "cultural products" in the context of development. Anthropos 93:469-494.

Armitage, D., F. Berkes, and N. Doubleday, editors. 2007. Adaptive co-management: collaboration, learning, and multi-scale governance. University of British Columbia Press, Vancouver, British Columbia, Canada.

Bailey, D. W., B. Dumont, M. F. WallisDeVries. 1998. Utilization of heterogeneous grasslands by domestic herbivores: theory to management. Annales de Zootechnie 47:321-333. http://dx.doi. org/10.1051/animres:19980501

Bali, A., and G. Kofinas. 2008. Voices of Caribou People. Conservation of Arctic Flora and Fauna (CAFF), Akureyri, Iceland. [online] URL: http://voicesproject.caff.is/ 
Barnhardt, R. 2005. Indigenous knowledge systems/Alaska native ways of knowing. Anthropology and Education Quarterly 36:8-23. http://dx.doi.org/10.1525/aeq.2005.36.1.008

Baskin, L. M. 1989. Herding. Pages 187-196 in R. J. Hudson, K. R. Drew, and L. M. Baskin, editors. Wildlife production systems: economic utilization of wild ungulates. Cambridge University Press, Cambridge, UK.

Baskin, L. M., and J. Hjalten. 2001. Fright and flight behavior of reindeer. ALCES 37:435-445.

Benn, B. 2001. Fall movements of the Porcupine Caribou Herdnear the Dempster Highway, August 2000. Report 01-07. Gwich'in Renewable Resource Board, Inuvik, Northwest Territories, Canada.

Berger, T. R. 1977. Northern frontier, northern homeland: the report of the Mackenzie Valley Pipeline Inquiry. Printing and Publishing, Supply and Services, Ottawa, Ontario, Canada.

Berkes, F. 1993. Traditional ecological knowledge in perspective. Pages 1-9 in J. T. Inglis, editor. Traditional ecological knowledge concepts and cases. Canadian Museum of Nature, Ottawa, Ontario, Canada.

Berkes, F. 2008. Sacred ecology: traditional ecological knowledge and resource management. Second edition. Taylor and Francis, New York, New York, USA.

Berkes, F. 2012. Sacred ecology: traditional ecological knowledge and resource management. Third edition. Taylor and Francis, Philadelphia, Pennsylvania, USA.

Berkes, F., and M. K. Berkes. 2009. Ecological complexity, fuzzy logic, and holism in indigenous knowledge. Futures 41:6-12. http://dx.doi.org/10.1016/j.futures.2008.07.003

Berkes, F., J. Colding, and C. Folke. 2000. Rediscovery of traditional ecological knowledge as adaptive management. Ecological Applications 10:1251-1262. http://dx.doi.org/10.1890/1051-0761 (2000)010[1251:ROTEKA]2.0.CO;2

Berkes, F., and N. J. Turner. 2006. Knowledge, learning and the evolution of conservation practice for social-ecological system resilience. Human Ecology 34:479-494. http://dx.doi.org/10.1007/ s10745-006-9008-2

Carlsson, L., and F. Berkes. 2005. Co-management: concepts and methodological implications. Journal of Environmental Management 75:65-76. http://dx.doi.org/10.1016/j.jenvman.2004.11.008

Caulfield, R. 1997. Greenlanders, whales and whaling: sustainability and self-determination in the arctic. Dartmouth College, Hanover, New Hampshire, USA.

Caulfield, R., S. Haley, A. Håkon Hoel, G. Hovelsrud-Broda, A. Jessen, C. Johnson, and K. Klokov. 2004. Resource governance. Pages 121-138 in N. Einarsson, J. N. Larsen, A. Nilsson, and O. R. Young, editors. Arctic human development report. Stefansson Arctic Institute, Akureyri, Iceland.

Chapin, F. S., G. P. Kofinas, and C. Folke, editors. 2009. Principles of ecosystem stewardship: resilience-based natural resource management in a changing world. Springer-Verlag, New York, New York, USA.
Clark, D. A., S. G. Clark, M. Dowsley. 2010. It's not just about bears: a problem-solving workshop on aboriginal peoples, polar bears, and human dignity. Arctic 63:124-127.

Collings, P. 1997. The cultural context of wildlife management in the Canadian north. Pages 13-40 in E. A. Smith, and J. McCarter, editors. A contested Arctic: indigenous people, industrial states, and the circumpolar environment. University of Washington Press, Seattle, Washington, USA.

Conradt, L., and T. J. Roper. 2005. Consensus decision making in animals. Trends in Ecology \& Evolution 20:449-456. http://dx. doi.org/10.1016/j.tree.2005.05.008

Couzin, I. D., J. Krause, N. R. Franks, and S. A. Levin. 2005. Effective leadership and decision-making in animal groups on the move. Nature 433:513-516. http://dx.doi.org/10.1038/nature03236

Cruikshank, J. 1998. The social life of stories: narrative and knowledge in the Yukon Territory. University of Nebraska Press, Lincoln, Nebraska, USA.

Dahle, B., E. Reimers, and J. E Colman. 2008. Reindeer (Rangifer tarandus) avoidance of a highway as revealed by lichen measurements. European Journal of Wildlife Research 54:27-35. http://dx.doi.org/10.1007/s10344-007-0103-5

Davis, A., and J. R. Wagner. 2003. Who knows? On the importance of identifying "experts" when researching local ecological knowledge. Human Ecology 31:463-489. http://dx.doi.org/10.1023/ A: 1025075923297

Dempster Highway Working Group. 1978. A Dempster Highway interim management proposal. Department of Indian and Northern Affairs Canada, Northern Roads and Airstrips Division, Whitehorse, Yukon, Canada.

Dumont, B., A. Boissy, C. Achard, A. M. Sibbald, and H. W. Erhard. 2005. Consistency of animal order in spontaneous group movements allows the measurement of leadership in a group of grazing heifers. Applied Animal Behaviour Science 95:55-66. http://dx.doi.org/10.1016/j.applanim.2005.04.005

Feldman, S. P. 1997. The revolt against cultural authority: power/ knowledge as an assumption in organization theory. Human Relations 50:937-955. http://dx.doi.org/10.1177/001872679705000804

Ferguson, M. A. D., and F. Messier. 1997. Collection and analysis of traditional ecological knowledge about a population of arctic tundra caribou. Arctic 50:17-28. http://dx.doi.org/10.14430/ arctic 1087

Fernandez-Gimenez, M. E., J. U. Hays, H. P. Huntington, R. Andrew, and W. Goodwin. 2008. Ambivalence toward formalizing customary resource management norms among Alaska native beluga whale hunters and Tohono O'odham livestock owners. Human Organization 67:137-150.

Folke, C. 2004. Traditional knowledge in social-ecological systems. Ecology and Society 9(3): 7. [online] URL: http://www. ecologyandsociety.org/vo19/iss3/art7/

Frank, J., and S. Frank. 1995. Neerihiinjik. We Traveled From Place to Place. Johnny Sarah Haa Googwandak. The Gwich'in Stories of Johnny and Sarah Frank. Alaska Native Language Center, Fairbanks, Alaska. 
Fraser, M. 1976. Highway could deplete herd: drastic steps sought for caribou. Whitehorse Star, 21 May.

Geertz, C. 1973. Thick description: toward an interpretive theory of culture. Pages 3-30 in C. Geertz. The interpretation of cultures: selected essays. Basic Books, New York, New York, USA.

Glaser, B. G., and A. L. Strauss. 1967. The discovery of grounded theory: strategies for qualitative research. Aldine, New York, New York, USA.

Government of Canada, Government of Yukon, Government of the Northwest Territories, Council for Yukon Indians, Inuvialuit Game Council, Dene Nation and Métis Association of the Northwest Territories. 1985. Porcupine Caribou Management Agreement. Indian and Northern Affairs, Government of Canada, Ottawa, Ontario, Canada.

Government of Canada, Government of Yukon, and Yukon First Nations. 1993. Umbrella Final Agreement between the Government Of Canada, the Council For Yukon Indians and the Government Of The Yukon. Aboriginal Affairs and Northern Development Canada, Ottawa, Ontario, Canada. [online] URL: http://www. aadnc-aandc.gc.ca/eng/1297278586814/1297278924701

Government of Canada and the Gwich'in Tribal Council. 1992. Gwich'in Comprehensive Land Claims Agreement. Indian and Northern Affairs, Government of Canada, Ottawa, Ontario, Canada.

Government of the Yukon Territory. 2002. Wildlife act: revised statutes of the Yukon. Government of the Yukon Territory, Whitehorse, Yukon, Canada.

Greer, S. C., and R. J. LeBlanc. 1992. Background heritage studies. Proposed Vuntut National Park. Northern Parks Establishment Office, Canadian Parks Service, Gatineau, Quebec, Canada.

Gubser, N. J. 1961. Comparative study of the intellectual culture of the Nunamiut Eskimos at Anaktuvuk Pass, Alaska. Dissertation. University of Alaska Fairbanks, USA.

Gunn, A., G. Arlooktoo, and D. Kaomayok. 1988. The contribution of the ecological knowledge of Inuit to wildlife management in the Northwestern Territories. Pages 22-30 in M. M. R. Freeman and L. N. Caybyn, editors. Traditional knowledge and renewable resource management in northern regions. Boreal Institute for Northern Studies, University of Alberta, Edmonton, Alberta, Canada.

Hart, E. J. 1995. Getting started in oral traditions research. Occasional Papers of the Prince of Wales Northern Heritage Centre 4. Government of the Northwest Territories, Yellowknife, Canada.

Houck, O. 2003. Tales from a troubled marriage: science and law in environmental policy. Science 302:1926-1929. http://dx.doi. org/10.1126/science. 1093758

Houde, N. 2007. The six faces of traditional ecological knowledge: challenges and opportunities for Canadian co-management arrangements. Ecology and Society 12(2): 34. [online] URL: http:// www.ecologyandsociety.org/vol12/iss2/art34/

Huntington, H. P. 2000. Using traditional ecological knowledge in science: methods and applications. Ecological Applications
10:1270-1274. http://dx.doi.org/10.1890/1051-0761(2000)010[1270: UTEKIS]2.0.CO;2

Huntington, H. P. 2005. "We dance around in a ring and suppose": academic engagement with traditional knowledge. Arctic Anthropology 42(1):29-32. http://dx.doi.org/10.1353/arc.2011.0101

Inglis, J. T., editor. 1993. Traditional ecological knowledge: concepts and cases. International Program on Traditional Ecological Knowledge, International Development Research Centre, Ottawa, Ontario, Canada.

Ingold, T. 1986. Reindeer economies: and the origins of pastoralism. Anthropology Today 2:5-10. http://dx.doi. org/10.2307/3032710

Kelsall, J. P. 1968. The migratory barren-ground caribou of Canada. Department of Indian Affairs and Northern Development, Canadian Wildlife Service, Ottawa, Ontario, Canada.

Kendrick, A. 2003. Caribou co-management in northern Canada: fostering multiple ways of knowing. Pages 241-267 in F. Berkes, J. Colding, and C. Folke, editors. Navigating social-ecological systems: building resilience for complexity and change. Cambridge University Press, Cambridge, UK. http://dx.doi.org/10.1017/ CBO9780511541957.015

Kofinas, G. 1998. The costs of power sharing: community involvement in Canadian Porcupine Caribou co-management. Dissertation. University of British Columbia, Vancouver, British Columbia, Canada.

Kofinas, G. 2005. Hunters and researchers at the co-management interface: emergent dilemmas and the problem of legitimacy in power sharing. Anthropologica 49:179-196.

Kofinas, G. P. 2009. Adaptive co-management in social-ecological governance. Pages 77-101 in F. S. Chapin, G. Kofinas, and C. Folke, editors. Principles of ecosystem stewardship: resiliencebased management in a changing world. Springer-Verlag, New York, New York, USA. http://dx.doi.org/10.1007/978-0-387-73033-2_4

Kofinas, G., G. Osherenko, D. Klein, and B. Forbes. 2000. Research planning in the face of change: the human role in reindeer/caribou systems. Polar Research 19:3-21. http://dx.doi. org/10.1111/j.1751-8369.2000.tb00323.x

Kruse, J., D. Klein, S. Braund, L. Moorehead, and B. Simeone. 1998. Co-management of natural resources: a comparison of two caribou management systems. Human Organization 57:447-458.

Light, S. S., L. H. Gunderson, and C. S. Holling. 1995. The Everglades: evolution of management in a turbulent ecosystem. Pages 103-168 in L. H. Gunderson, C. S. Holling and S. S. Light, editors. Barriers and bridges to the renewal of ecosystems and institutions. Columbia University Press, New York, New York, USA.

McCandless, R. G. 1985. Yukon wildlife: a social history. University of Alberta Press, Edmonton, Alberta, Canada.

McClellan, C. 1987. Part of the land, part of the water: a history of the Yukon Indians. Douglas \& McIntyre, Vancouver, British Columbia, Canada.

McComb, K., C. Moss, S. M. Durant, L. Baker, and S. Sayialel. 2001. Matriarchs as repositories of social knowledge in African 
elephants. Science 292:491-494. http://dx.doi.org/10.1126/ science. 1057895

Miller, F. L., C. J. Jonkel, and G. D. Tessier. 1971. Group cohesion and leadership response by barren-ground caribou to man-made barriers. Arctic 25:193-202.

Moller, H., F. Berkes, P. O’Brian Lyver, and M. Kislalioglu. 2004. Combining science and traditional ecological knowledge: monitoring populations for co-management. Ecology and Society 9(3): 2. [online] URL: http://www.ecologyandsociety.org/vol9/ iss $3 / \operatorname{art} 2$

Morrow, P., and C. Hensel. 1992. Hidden dissension: minoritymajority relationships and the use of contested terminology. Arctic Anthropology 29(1):38-53.

Nadasdy, P. 1999. The politics of TEK: power and the "integration" of knowledge. Arctic Anthropology 36:1-18.

Nadasdy, P. 2003b. Hunters and bureaucrats: power, knowledge, and aboriginal-state relations in the southwest Yukon. University of British Columbia Press, Vancouver, British Columbia, Canada.

Nadasdy, P. 2003a. Reevaluating the co-management success story. Arctic 56:367-380.

Nadasdy, P. 2007. The gift in the animal: the ontology of hunting and human-animal sociality. American Ethnologist 34:25-43. http://dx.doi.org/10.1525/ae.2007.34.1.25

Natcher, D. C., S. Davis, and C. G. Hickey. 2005. Co-management: managing relationships, not resources. Human Organization 64 (3):240-250.

Nellemann, C., I. Vistnes, P. Jordhøy, and O. Strand. 2001. Winter distribution of wild reindeer in relation to power lines, roads and resorts. Biological Conservation 101:351-360. http://dx.doi. org/10.1016/S0006-3207(01)00082-9

Osherenko, G. 1988. Sharing power with native users: comanagement regimes for Arctic wildlife. CARC Policy Paper 5. The Canadian Arctic Resources Committee, Ottawa, Ontario, Canada.

Ostrom, E. 1990. Governing the commons: the evolution of institutions for collective action. Cambridge University Press, New York, New York, USA. http://dx.doi.org/10.1017/CBO9780511807763

Padilla, E. 2010. Caribou leadership: a study of traditional knowledge, animal behavior, and policy. Thesis. University of Alaska, Fairbanks, Alaska, USA.

Page, R. 1986. Northern development: the Canadian dilemma. McClelland and Stewart, Toronto, Ontario, Canada.

Paine, R. 1988. Reindeer and caribou Rangifer tarandus in the wild and under pastoralism. Polar Record 24:31-42. http://dx.doi. org/10.1017/S0032247400022324

Paine, R. 1994. Herds of the tundra: a portrait of Saami reindeer pastoralism. Smithsonian Institution Press, Washington, D.C., USA.

Parlee, B., M. Manseau, and Łutsël K'é Dene First Nation. 2005. Using traditional knowledge to adapt to ecological change: Denésǫłiné monitoring of caribou movements. Arctic 58 (1):26-37.
Perecman, E., and S. R. Curran, editors. 2006. A handbook for social science field research: essays and bibliographic sources on research design and methods. Sage, Thousand Oaks, California, USA. http://dx.doi.org/10.4135/9781412983211

Peter, A., and D. Urquhart. 1991. One caribou herd, two native cultures, five political systems: consensus management on the Porcupine Caribou range. Pages 321-325 in Transactions of the Fifty-sixth North American Wildlife and Natural Resources Conference. Wildlife Management Institute, Washington, D.C., USA.

Phuthengo, T. C., and R. Chanda. 2004. Traditional ecological knowledge and community-based natural resource management: lessons from a Botswana wildlife management area. Applied Geography 24:57-76. http://dx.doi.org/10.1016/j.apgeog.2003.10.001

Pinkerton, E. 1989. Attaining better fisheries management through co-management: prospects, problems, and propositions. Pages 3-33 in E. Pinkerton, editor. Co-operative management of local fisheries: new directions for improved management and community development. University of British Columbia Press, Vancouver, British Columbia, Canada.

Pinkerton, E. 1994. Conclusions: where do we go from here? Pages 51-60 in B. Sadler and P. Boothroyd, editors. The future of traditional ecological knowledge and resource management in Native communities. Traditional ecological knowledge and modern environmental assessment. Canadian Environmental Assessment Agency, International Association for Impact Assessments, and University of British Columbia, Centre for Human Settlements, Vancouver, British Columbia, Canada.

Pinkerton, E. 1999. Factors in overcoming barriers to implementing co-management in British Columbia salmon fisheries. Conservation Ecology 3(2): 2. [online] URL: http://www. consecol.org/vol3/iss2/art2/.

Pinkerton, E. 2009. Coastal marine systems: conserving fish and sustaining community livelihoods with co-management. Pages 241-257 in F. S. Chapin, G. Kofinas, and C. Folke, editors, Principles of ecosystem stewardship: resilience-based management in a changing world. Springer-Verlag, New York, New York, USA. http://dx.doi.org/10.1007/978-0-387-73033-2 11

Porcupine Caribou Management Board (PCMB). 1995. Porcupine Caribou Management Board annual report. PCMB, Whitehorse, Yukon, Canada.

Porcupine Caribou Management Board (PCMB). 2000. Porcupine Caribou Management Board annual report. PCMB, Whitehorse, Yukon, Canada.

Porcupine Caribou Management Board (PCMB). 2006. Porcupine Caribou Management Board annual report. PCMB, Whitehorse, Yukon, Canada.

Porcupine Caribou Management Board (PCMB). 2007. Porcupine Caribou Management Board annual report. PCMB, Whitehorse, Yukon, Canada.

Porcupine Caribou Management Board (PCMB). 2010. Harvest management plan for the Porcupine Caribou Herd in Canada. PCMB, Whitehorse, Yukon, Canada. [online] URL: http://www. taiga.net/pcmb/documents/HMP Final.pdf 
Rands, S. A., G. Cowlishaw, R. A. Pettifor, J. M. Rowcliffe, and R. A. Johnstone. 2003. Spontaneous emergence of leaders and followers in foraging pairs. Nature 423:432-434 . http://dx.doi. org/10.1038/nature01630

Renaud, R. 1978. Promotion for Dempster area. The Northern Times, 8 September.

Richard, P. R., and D. G. Pike. 1993. Small whale co-management in the eastern Canadian Arctic: a case history and analysis. Arctic 46(2):138-143.

Sherry, E., and H. Myers. 2002. Traditional environmental knowledge in practice. Society and Natural Resources 15:345-358. http://dx.doi.org/10.1080/089419202753570828

Sherry, E., and Vuntut Gwitchin First Nation. 1999. The land still speaks: Gwitchin words about life in Dempster country. Vuntut Gwitchin First Nation, Old Crow, Yukon, Canada.

Singleton, S. 1998. Constructing cooperation: the evolution of institutions of co-management. University of Michigan Press, Ann Arbor, Michigan', USA.

Slobodin, R. 1962. Band organization of the Peel River Kutchin. Bulletin 179, National Museum of Canada, Ottawa, Ontario, Canada.

Slobodin, R. 1981. Kutchin. Pages 514-532 in J. Helm, editor. Handbook of North American Indians: subarctic 6. Smithsonian Institute, Washington, D.C., USA.

Smith, B., and D. Cooley. 2003. Through the eyes of hunters: how hunters see caribou reacting to hunters, traffic, and snowmachines near the Dempster Highway. Yukon Government Department of Environment, Whitehorse, Yukon, Canada.

Statistics Canada. 2006. Canadian census. Ottawa, Ontario, Canada.

Stevenson, M. G. 1996. Indigenous knowledge in environmental assessment. Arctic 49:278-291.

Stewart, A. M., D. Keith, and J. Scottie. 2004. Caribou crossings and cultural meanings: placing traditional knowledge and archaeology in context in an Inuit landscape. Journal of Archaeological Method and Theory 11:183-211. http://dx.doi. org/10.1023/B:JARM.0000038066.09898.cd

Strauss, A. L. 1987. Qualitative analysis for social scientists. Cambridge University Press, New York, New York, USA. http:// dx.doi.org/10.1017/CBO9780511557842

Taiepa, T., and P. Lyver, P. Horsley, J. Davis, M. Bragg, and H. Moller. 1997. Co-management of New Zealand's conservation estate by Maori and Pakeha: a review. Environmental Conservation 24(3):236-250. http://dx.doi.org/10.1017/S0376892997000325

Usher, P. J. 1986. The devolution of wildlife management and the prospects for wildlife conservation in the Northwest Territories. Canadian Arctic Resource Committee (CARC) Policy Paper 3. CARC, Ottawa, Ontario, Canada.

Usher, P. J. 1993. The Beverly-Kaminuriak caribou management board: an experience in co-management. Pages 111-120 in J. T. Inglis, editor. Traditional ecological knowledge concepts and cases. Canadian Museum of Nature, Ottawa, Ontario, Canada.
Warbelow, C., D. Roseneau, and P. Stern. 1975. The Kutchin caribou fences of northeastern Alaska and the northern Yukon. Page 129 in R. D. Jakimchuck, editor. Studies of large mammals along the proposed Mackenzie Valley gas pipeline route from Alaska to British Columbia. Canadian Arctic Gas Limited and Alaskan Arctic Gas Study Company Arctic gas biological report series 32 .

Wavey, R. 1993. International workshop on indigenous knowledge and community-based resource management: keynote address. Pages 11-16 in J. T. Inglis, editor. Traditional ecological knowledge concepts and cases. Canadian Museum of Nature, Ottawa, Ontario, Canada.

Wilson, S. 1996. Gwich'in native elders: not just knowledge, but a way of looking at the world. University of Alaska Fairbanks, Fairbanks, Alaska, USA.

Wolfe, S. A., B. Griffith, and C. A. Gray Wolfe. 2000. Response of reindeer and caribou to human activities. Polar Research 19:63-73. http://dx.doi.org/10.1111/j.1751-8369.2000.tb00329.x

Yin, R. K. 2009. Case study research: design and methods. Fourth edition. Sage, Thousand Oaks, California, USA. 